\title{
Innovative Leadership Ridwan Kamil in Social Media in Bandung City
}

\author{
Fitri Melawati \\ Doctoral Candidate in Public Administration \\ Universitas Padjadjaran \\ Bandung, Indonesia \\ fitrimelawati@ymail.com
}

\author{
Riki Satia Muharam \\ Administrasi Publik \\ Universitas Muhammadiyah Bandung, STIA CIMAHI, \\ STIKEP PPNI Jawa Barat \\ Indonesia \\ rikisatiamuharam@yahoo.co.id
}

\begin{abstract}
Today, Politics is undergoing change, change means to provide opportunities for direct election of people who are not involved daily in practical politics can be a leader in the area, Ridwan Kamil position represents the opportunity. This used to be the leader should go into the bureaucracy or become members of political parties. Today, everyone has the same opportunity. Both of these technological changes that cannot be avoided, wear first mobile phone for sms and call his business, now use mobile phones to all matters, examples of two different generations. Due to the ease of using a smartphone, information flow becomes faster, there is less community groups have time to read newspapers, watch $\mathrm{TV}$, because it has shifted to online. Thus was born a new media, social media such thing, is popular in Indonesia, one of the contributors to happiness is social interaction the duo could be physical, and can be digital interaction. Government of Bandung is measured in three things : integrity, public services, and professional. Public expectations, had not a channel, send a formal letter. This is because the public expectation is high, the local government is only $20 \%$ who have twitter, now all departments have a twitter account. In Bandung there are 200 news per day in social media uploads, as performance accountability, the Department of preaching activities requested or not requested, respond, communicate and answer complaints. Today officials or leaders cannot escape from the expectations of the public, where public expectations by channels through social media. This paper focuses on how Innovative Leaderships Ridwan Kamil in Social Media in Bandung City.
\end{abstract} Media

Keywords-Innovative, Leaderships, Ridwan Kamil, Social

\section{INTRODUCTION}

There are three main factors that can shape the character of leadership, namely creativity, energy and philosophical insights. The combination of these factors can stimulate the enthusiasm of the leader himself, so he constantly moving dynamic and adaptive. Enthusiasm comes from the Greek root word Ethos which means "of the spirit that dwells in". The enthusiasm in leadership is often interpreted as the power of adaptability - the ability to adapt - to changing circumstances and conditions, regulations and other demands. Although many circumstances that cannot be controlled completely, the leader with enthusiasm to have the intelligence to change and find new ways, so that the decisions taken are effective and efficient while overcoming various problems. Power is what form toughness adaptability, character, and leadership integrity, which is an attitude that is not easily give up, steadfast and loyal to the principle, but flexible and constantly seek a breakthrough in the face of obstacles.

Hurdle is an inevitable problem in an organization, especially when the leader will start innovating. Obstacles often impede acceleration to change, and therefore to deal with the necessary time and energy. Often confront obstacles in the midst of the rate of creativity and sometimes stop creative ideas to implement innovation in organizations. There are two obstacles that normally we met, namely: first, the obstacles that impede an individual basis, so that the person affected and creativity stalled. Second, obstacles that affect the organization so that stalled become an innovative organization.

For a leader who is strong and full of enthusiasm, obstacles or challenges as difficult as any - from the standpoint of philosophy - understood as "lab-alive" to learn firsthand how to deal with distress, discomfort and shock as a test of the resilience of the personality and the character himself, either when leaders are dealing with the public or when brooding alone. A leader will be fully aware that the success of the organization in the future will be largely determined by the leadership, especially in optimizing opportunities, to continue to encourage all members of the organization to think ahead, to grow and develop creativity and innovation.

Globalization takes place rapidly with the development of increasingly sophisticated technology has colored the early era of the 21 st century is marked by rapid global competition in all fields. The impact appeared to have touched almost all areas of life, not to mention public sector organizations. While one's consciousness will affect every aspect of life, especially in the decision-making process. One indicator of a healthy organization is a leader in the commitment to balance the 
performance of the team, the team members to contribute in providing optimal performance.

This needs to be done considering the increasingly complex demands of public and community service needs which multiply so as to realize the ideal level of governance implementation of good governance requires serious effort. On the other hand, society's demands that must be serviced more complex bureaucracy and increasing the quantity, in addition to the level of public awareness are also higher. This condition requires public organizations ready to make fundamental changes to the organizational towards good governance.

\section{LITERATURE}

The word innovation or innovation comes from the Latin innovation meaning renewal or renovation, based on Novus (new). In the Wikipedia site is defined as "the process" and / or "the result of" development and / or use / mobilization of knowledge, skills (including skills technological) and experience to create or improve a product (goods and / or services), process, and / or systems the new, which provide meaningful value or significantly (mainly economic and social). Innovation related to the creative activity changes and improvements. Meaningful change also introduces something new to replace the old lead to something better. Change is a process that must happen, because in order to survive we have to adapt (adaptive) with developments both in the internal and external environments.

According to Morse and Burs (2007: 6), in the last decade of public administration experts reveal a case which symbolizes the changing environment in the form of a study of government (government) to "settings" (governance). The setting is understood more than what is done by the government, but also includes collective action to solve public problems. This new arrangement to change the emphasis of the role of the agent toward the use of "instruments" broadly to include a contract with another party, the collaboration between agencies or between sectors, and so forth (Salamon 2002). The transformation of these new arrangements needs to be integrated with the transformation of leadership in the public sector in the era of globalization.

Observing the current conditions in which we are already in the third millennium, and then we would have been in the context of the new phase of globalization - which by Friedman labeled "Globalization 3.0" - built on the foundations of social, economic, and political. According to him, "Globalization 1.0" (1492-1800) was marked by nation states "breaking down barriers and together embrace the world, directing global integration (Morse et al 2007: 9). The world is changing in size from "great" to "medium". "Globalization 2.0" (18002000) was marked by the expansion of multinational companies. Advances in hardware aspects such as the railways did in the beginning and telecommunications in the end, has been directing an increased global integration and changing the face of the world into a size "small" (Morse et al 2007: 89). According to Friedman, the period in the new millennium, the so-called "globalization 3.0" today is characterized by the convergence of strength, because the most obvious evidence is the lack of progress on aspects of the software and information technology infrastructure. Current world-sized "small" and fields for each individual game is flat and flat.

Transformational leadership can be learned in the leadership model developed by Avolio and Bass (1991), Full Range Leadership models. In it there and transactional leadership and transformational leadership. The elements of both types of leadership are formed by the vertical axis that measures the effectiveness and sources horizontal measure engagement (passive - active). Transactional leadership tends toward quadrant ineffective and passive; transformational leadership quadrant tends toward an active and effective. Bass (1991) identified eight dimensions of leadership behaviors that include two types of leadership, namely: 1) Conduct idealization (idealized influence), a leader who has high standards to our morals and ethics; 2) inspirational motivation, the leader who had a strong vision for the future based on the value and the ideal; 3) intellectual stimulation, which led the challenge to the norms of the organization, lead to divergent thinking, and encourages subordinates to formulate innovative strategies; 4) Consideration of individual (individual consideration), the behavior of the leadership directed to create creativity, introspection, imagination, wealth of resources, and extensive knowledge and jelly.

Having understood the meaning and significance of leadership, it is necessary to understand the notion of public leadership is based on three perspectives according to Morse and Buss (in Morse et al 2007: 4-5), below. First, political leadership or policy elite, focused on political leaders, namely those who are elected or appointed. Leader, according to this perspective leads to officials who occupy key positions in government, both as legislators and senior executives. Second, the leadership of public organizations focused on formal leadership in public organizations (read: government), namely leadership positions in public organizations and means used by these leaders in directing the organization and generating output. Third, the style of the lead actors are commonly referred to as "public leadership" or "collaborative leadership" or "leadership for the common good" leadership perspective is the focus instead to the "leader" of the public (those who occupy formal positions in the government), but rather as a process of public value creation inside and outside of government and at all levels of the organization. Public leadership is understood as a process that occurs outside public organizations and the formal leadership alone. The public leadership reflect the reality of an effort "to share world power", because the setting is a product of a number of organizations - not just the government alone (Buss in Morse and Morse et al 2007: 4-5). 


\section{RESEARCH METHOD}

The method used is the method of literature study. This study utilized the literature as a secondary data source to obtain research data. Source libraries used in the form of books, e-books, journals, e-journal, and the results of a research report discusses the leaderships. The analysis was conducted by reviewing literature from various secondary data sources that have been reduced and synthesized in accordance with the needs of the discussion in this study.

\section{DISCUSSION}

Bandung is a city of 2.5 million in the west java, in Indonesia, metropolitan city, the climate is very cold, the reason people love Bandung because of the weather, but as a metropolis Bandung City face a some many issue and opportunity as usual, Bandung is the second tourist destination in Indonesia, Bandung rely save 6 milion tourist coming to the city, so the last couple years is dramaticcaly change the landscape of Bandung, to more service oriented city, and also Bandung has more than 80 university and colleges, $40 \%$ under 40 years old, so city of view and educated.

Ridwan Kamil is the current Mayor of Bandung City, Indonesia. He is a famous Indonesian architect. He is also an educator in Bandung Institute of Technology (ITB) at Architecture Department, an urban designer and a writer. After receiving his master degree in Urban Planning from University of California at Berkeley in 2001, he worked in New York, San Francisco and Hong Kong. After several years, he went back to Indonesia and started to serve as a lecturer in ITB at Department of Architecture.

Together with some students from Department of Urban Planning, Design Product, and Electrical Engineering in ITB, he invented Enerbike, a bike prototype that can generate electricity. He also established his own architecture and design firm, Urbane, stands for 'Urban Evolution' (some people might also refer it as "Urang Bandung Euy", which means "Bandung People" in Bahasa Indonesia) in 2004. Being responsive with environment and having remarkable artistic values, Urbane Indonesia was honored as one of 10 best architecture firms in Indonesia. In 2006, Ridwan Kamil won British Council's Young Creative Entrepreneur Award as Indonesian representative in International Young Design Entrepreneur of the Year award. Three years later, he was declared as Architect of the Year by Elle Décor Magazine.

Together with Urbane, Ridwan Kamil has handled many architecture works in various countries such as Singapore, Thailand, Bahrain, China, Vietnam, United Arab Emirates, and also Indonesia. Generally, the works are development of the urban area or mega projects. Among the high-profile international projects completed by Urbane Indonesia is the Aceh Tsunami Museum in Banda Aceh, Indonesia. International projects handled by Ridwan Kamil and Urbane Indonesia include the Marina Bay Waterfront Master in Singapore, Urban Resort Master Plan Sukhothai in Bangkok,
Ras Al Kaimah Waterfront Master in Qatar, as well as the Residential District 1 Saigon South Master Plan in Saigon.While in China there is Shao Xing Waterfront Masterplan, Beijing CBD Master Plan, and the Guangzhou Science City Master Plan. Urbane Indonesia has been honored in the Building Design Business category of the BCI Asia Top 10 Awards for three consecutive years $(2008,2009,2010)$.

As an individual and through the work of Urbane Indonesia, he is committed to grass-roots urban design that empowers urban poor populations. He firmly holds the view "life is collaboration", thus he believes that a lot of public issues can be solved with collaboration. He has been a pioneer in the "Indonesia Berkebun" movement to build amateur gardens in cities across Indonesia. As of 2011, the community project is established in fourteen cities in Indonesia, with membership approaching 4,000. He has also established many other social communities, such as Bandung Creative City Forum (BCCF), Bandung Citizen Journal, and Konsep One Village One Playground.

Politics today is undergoing change, change means to provide opportunities for direct election of people who are not involved daily in practical politics can be a leader in the area, Ridwan Kamil position represents the opportunity. This used to be the leader should go into the bureaucracy or become members of political parties; today everyone has the same opportunity. Both of these technological changes that cannot be avoided, wear first mobile phone for sms and call his business, now use mobile phones to all matters, examples of two different generations. Due to the ease of using a smartphone, information flow becomes faster, there is less community groups have time to read newspapers, watch TV, because it has shifted to online. Thus was born a new media, social media such thing, is popular in Indonesia, one of the contributors to happiness is social interaction the duo could be physical, and can be digital interaction. Government of Bandung is measured in three things: integrity, public services, and professional. Public expectations had not had a channel, send a formal letter. This is because the public expectation is high; the local government is only $20 \%$ who have twitter, now all departments have a twitter account. In Bandung there are 200 news per day in social media uploads, as performance accountability, the Department of preaching activities requested or not requested, respond, communicate and answer complaints. Today officials or leaders cannot escape from the expectations of the public, where public expectations by channels through social media.

Invented and developed technology is to meet human needs for convenience, practicality and comfort in life. The more complex human needs, the technology also required to be continuously updated to simplify the complexity of humans. The process for this update is closely associated with the presence of creativity and innovation. Internet technology is a technology that was born from the creativity and relentless innovation, makes it easy to connect without having impeded 
by barriers, distance, and place. In the area of governance, social media presence makes the wheels of government in Bandung can move faster. A mayor and his officials will no longer drive the wheels of government alone. With Twitter, Bandung city government can work together to develop the region in a way that is very easy and fun.

Internet gave birth to openness and transparency in many areas of life, one of them in and bureaucracy. With the presence of Internet technology without borders (borderless), bureaucratic rigidity can be disbursed. Citizens who usually have to queue and forth to get a recommendation letter, ID card, and other administrative services, services by using the online system is able to break the lines of bureaucracy.

The key to the presence of the company based on information technology and communication have originated from the willingness of the authorities, in facilitating communication between the community and the city government, Ridwan Kamil makes Internet-based reporting system, such as twitter or facebook. People who want to report an issue related to public services or contacting able to access the account. Reports created in addition to real time can also include a photo (as the database identifier), a video report activities (reducing the chance of manipulating), direct communication or videophone via Skype or IM (show my camera), and multimedia reports (web and SMS) via Twitter, In such a manner, there are so many bureaucratic chains which can be disconnected, saving the cost, time, and the community was served well.

To reform the government, very clear vision of open government, make data available online for public, something that never done before, also use social media to manage the city, so Bandung is the only city to have all department has a twitter account to communicate the people, so the last eight month of Ridwan Kamil, mayorship, is transform to make people, how people communicate with the government, they report, they get respond, they appreciate, the process, so this technology reform combine the long term vision for, public infrastructure, this is something that will proceed in the next five of Ridwan Kamil term.

By having a Twitter account, every department of government and its officials can be optimized in establishing interaction and communication with the public. The problems are in the midst of society can be identified and dealt with more quickly. Through this policy, born 23 Twitter accounts of government departments and other work units, including districts and villages in the city of Bandung.

Ridwan Kamil made several breakthroughs in implementing the various work programs in the middle of the ice bureaucracy. Breakthrough with reviving the city parks, provide penalties to smokers in public places, to accelerate the creation of a birth certificate for their citizens. Ridwan Kamil almost routine "greet" citizens through social media. Take full advantage of social media to engage in dialogue directly with citizens, eliminating distance communication, can greet people through social media. All citizens can ask Ridwan Kamil, then Ridwan Kamil replied, utilizing Facebook and Twitter in optimizing social media in communicating with citizens. In Bandung whose population of 2.6 million, which has Facebook, 2.3 million. From this fact, Ridwan Kamil then choose to utilize social media to connect with its citizens. So all activities Ridwan Kamil informed in social media, also answered questions, arguing against criticism.

Camera technology which is embedded in the mobile phone is used for something much more useful, one example is submitting evidence to corroborate the report. The activities reported in the form of photos via cell phones, in addition to saving time, more credible and more accountable truth when compared to oral or written statements.

Communication and similar reports are also not only based on the program of work units in the city government Bandung, Bandung citizen can directly report back on how the working units within the Government of Bandung provide the best service to the community.

Not optimal realization of the program of Bandung City, this time not because of a bad program, lack of funds, or the absence of the parties execute. One point is the lack of effective inhibitory informs delivery to the public. By utilizing social media, the government of Bandung can inform programs, to dialogue, to accommodate the aspirations of citizens, both in the form of complaints, feedback and criticism.

One man advantage compared to other creatures is the ability to see and understand the reality and then interpret it. String of words can be inspiring, inflame the soul, awaken the spirit that can change the life of a human being, and even change the fate of a nation. Ridwan Kamil not stop sharing the spirit, giving pneumatic a better life to the citizens of Bandung with positive words via social media.

Social media has become an integral part of modern society is a form of the creativity of the poles in the field of information technology. Communication technology is present to replace the dominance of print and electronic media were first there is coloring people's lives.

Like the other media, social media can be used as a tool to spread the virtues and benefits, move the masses to improve the condition of a city, becomes a tool of management control in government, become the media of information and education for the public. On the other hand, social media can be used as a means to spread ugliness, hatred, provocation and hostility, therefore, anyone who wanted to come into contact with social media should understand norm in it. As in the real world, social order in the virtual world has rules that must be obeyed, both written and has consequences if violated criminal 
law or unwritten rule that, if broken, will bear the punishment that is both socially and psychologically.

\section{CONCLUSION}

Innovative leader is a person who takes risks by constantly creating new things. Globalization takes place rapidly with the development of increasingly sophisticated technology has colored the early era of the 21 st century is marked by rapid global competition in all fields. The impact appeared to have touched almost all areas of life, not to mention public sector organizations. On the other hand, society's demands that must be serviced more complex bureaucracy and increasing the quantity, in addition to the level of public awareness are also higher. This condition requires public organizations ready to make fundamental changes to the organizational towards good governance. Technological changes that cannot be avoided, due to the ease of using a smartphone, information flow becomes faster, there is less community groups have time to read newspapers, watch $\mathrm{TV}$, because it has shifted to online. Thus was born a new media, social media such thing, is popular in Indonesia, one of the contributors to happiness is social interaction the duo could be physical, and can be digital interaction. Today officials or leaders cannot escape from the expectations of the public, where public expectations by channels through social media.

\section{REFERENCES}

[1] Bass, B. M. (1985). Leadership and Performance Beyond Expectations. New York : Free Press.

[2] Bass, Bernard M. (1990). Handbook of Leadership. New York: Free Press.

[3] Bass, B. M., \& Avolio, B. J. (1993). Transformational Leadership: A Response To Critiques. In M. M. Chemer \& R. Ayman (Eds.), Leadership Theory and Research: Perspectives and Directions (Pp. 4980). San Diego, CA: Academic Press

[4] Bass, B. M. (1997). Does The Transactional-Transformational Leadership Paradigm Transcend Organizational and National Boundaries? American Psychologist, 52, 130-139.

[5] Bass, B. M. (1998a). The Ethics of Transformational Leadership. In J. B. Ciulla (Ed.), Ethics, The Heart of Leadership. Westport, CT: Quorum.

[6] Bass, B. M. (1998b). Transformational Leadership. Mahwah, NJ: Lawrence Erlbaum.

[7] Bass, B. M. (1998c). Transformational Leadership: Industrial, Military, And Educational Impact. Mahwah, NJ: Lawrence Erlbaum.

[8] Bass, B. M., \& Steidlemeier, P. (1999). Ethics, Character and Authentic Transformational Leadership Behavior. Leadership Quarterly, 10(2), 181-217

[9] Kamil, Ridwan. 2014. \#TETOT, aku, kamu, dan media sosial. Bandung : Sygma Creative Media Corp.

[10] Kamil, Ridwan. 2015. Mengubah Dunia Bareng-Bareng. Bandung : Kaifa.

[11] Kyle, David. T. 2004. The Four Power of Leadership. Batam: Karisma Press.

[12] Morse, Richardo S, Terry F. Buss and C Morgan Kinghorn. 2007. Transforming Public Leadership for the 21st Century, M.E. Sharpe, Armonk New York. 